\title{
ENGLISH AS A WORLD LANGUAGE IN SCANDINAVIA AND ELSEWHERE (PART 2) ${ }^{1}$
}

Keywords: English, global language, English in academia, English in business, internationalization

\begin{abstract}
This is the second part of a paper dealing with the concept of English as a "world" or "global language". Here, results from two research projects conducted in Denmark are presented. They investigated the role of languages in academia and in businesses with a global perspective. Data are taken from Denmark and in part Japan. Two different narratives of English as a world language emerge.
\end{abstract}

\section{Language, interaction and the globalized world}

In the second part of this paper, I want to report on insights gained in two largescale research projects centred at Roskilde University in Denmark. The first one was "Cultural and linguistic practices in the international university" (CALPIU), based on an international network in Europe, Asia and Australia, which between 2007 and 2012 investigated developments in higher education that followed from an increased transnational exchange of students, teachers and researchers. This was

1 I would like to thank my colleagues in both the CALPIU (2007-2013) and LInGCorp (2013-2016) Projects, especially Bent Preisler, Anne Fabricius, Sonja Barfod, Dorte Lønsmann, Kamilla Kraft, Spencer Hazel, Janus Mortensen and Ole Nedergaard Thomsen, for inspiring discussions and data sharing. Thanks also go to Sharon Millar and Linus Salö for helpful comments.

As its companion paper, this paper is based on my Keynote given at The Fourteenth International Conference on English and American Literature and Culture. New Perspectives in English and American Studies, 20 April, 2017 at the Jagiellonian University in Kraków. 
followed by a different project, "Language and interaction in the globalized Corporation" (LInGCorp), in cooperation with researchers from Copenhagen Business School, the University of Copenhagen and the University of Nottingham, which tried to map the impact of global orientation on language choice, interaction and language policy in companies and organizations especially in Denmark, but also with some data collection in Japan. Both projects acknowledged the role that English plays in all these developments. They also sought to approach the analysis of these developments with an ecological angle by neither focusing on the pre-eminent role of English alone nor concentrating on the competition between English and the local language; the global-local contrast seems to be suggested by the once fashionable concept of "glocalization", ignoring the role of other, especially regional languages. Rather, we tried to take in all the languages that play a role in these processes.

\section{The universities}

Table 3 gives an admittedly schematic account of the history of Danish universities since their beginnings (the first university within the borders of present-day Denmark was founded in Copenhagen in 1479) from the point of view of the languages used. While this development and its timing were particular to Denmark in detail, the general trends were European (as analyzed in Schiewe 2000 and Bull 2004).

\begin{tabular}{|c|c|c|c|}
\hline University type & Period & $\begin{array}{l}\text { Legitimizing } \\
\text { principle }\end{array}$ & $\begin{array}{c}\text { Language } \\
\text { of instruction }\end{array}$ \\
\hline $\begin{array}{l}\text { Medieval and early } \\
\text { modern university }\end{array}$ & $\begin{array}{l}15^{\text {th }} \text { and } 16^{\text {th }} \\
\text { century }\end{array}$ & $\begin{array}{l}\text { auctoritas } \\
\text { (authority) }\end{array}$ & Latin \\
\hline $\begin{array}{l}\text { Enlightenment } \\
\text { university }\end{array}$ & $\begin{array}{l}17^{\text {th }} \text { and } 18^{\text {th }} \\
\text { century }\end{array}$ & ratio (reason) & $\begin{array}{l}\text { Latin, other European } \\
\text { languages and Danish }\end{array}$ \\
\hline National university & $\begin{array}{l}19^{\text {th }} \text { and } 20^{\text {th }} \\
\text { century }\end{array}$ & nation & Danish \\
\hline $\begin{array}{l}\text { Post-national } \\
\text { university }\end{array}$ & $\begin{array}{l}\text { end of } 20^{\text {th }}, \text { and } \\
21^{\text {st }} \text { century }\end{array}$ & market & English and Danish \\
\hline
\end{tabular}

Table 3. Historical development of Danish universities, according to Mortensen and Haberland (2012: 192)

It may not be so surprising that the national university, established in the first half of the $19^{\text {th }}$ century, was replaced and superseded by a market-oriented university in the late $2 \mathrm{O}^{\text {th }}$ century, as this was in keeping with general ideological trends of the time. However, it is remarkable that this market soon was considered not as national only, but as international. This applies to the competition between universities about placements in rankings, competition to attract the best and most 
students, competition to attract the best teachers, and competition about best to prepare their students for the competition on the job market. (Somehow it was never resolved whether students in this model are customers or products of the universities.) The national university was by no means monolingual; it actually expected its students to read academic literature in several foreign languages. But at least it could assume that it was held together by one common language that was the one used in teaching, the national language. If the market oriented university turns international, a common language is no longer a given. But since globalization already had been firmly associated with English, the solution appeared to be at hand. On the one hand, offering courses in English would open the universities towards the world and attract the best students and researchers (and probably also teachers). According to a memorandum by the Danish Ministry of Science, Technology and Development in 2009, "The universities ought to define relevant aims for programmes offered in English in order to be able to attract the best students and researchers nationally and internationally" (original in Danish, quoted in Haberland, Preisler 2015: 26). On the other hand, this would also open career opportunities for the students abroad. Dean Børge Obel of Århus Business School combined both aspects in an interview in 2007: "English language study programs attract the best foreign teaching staff and students and create a unique international research and study environment which will help kickstart an international career for our students" (quoted in Haberland, Preisler 2015: 26).

For university administrators, English might look like "the most cost- and hasslefree" solution (Coleman 2013: xiv) to the challenges of internationalization; for others, it might seem that it is as much part of the problem as part of the solution. One of the problems is the "linguistic paradox of internationalization", viz. that in the new, market-oriented internationalized university, fewer languages can be used rather than more, since the number of languages present has increased while the number of shared languages has decreased, maybe even down to one, viz. English (Fabricius et al. 2017: 583).

Especially in Sweden, it has been suggested that the real idea with English-language courses is not to attract transnationally mobile students, "but an attempt by universities to strengthen their position at home. Such a strategy relies more on the university being associated with an international approach than participating in a tug-of-war over the best incoming students" (Airey et al. 2017: 567; cf. also Dalberg 2013).

One interesting - albeit admittedly secondary - issue is the ambiguous role of the English native speaker. In the early days of English medium programs in Denmark, universities tried to attract students from English speaking countries, who were almost held hostage in an attempt to force the local students not to slip into Danish. But while Danish students are "at home" and therefore feel "that they need to do something 'out of the ordinary' in order to be 'international"', visiting students (which include students from English-speaking countries) rather "may be motivated to display a willingness to align themselves ... through participation in 
the local language" (Hazel, Mortensen 2013: 269). ${ }^{2}$ But the ambiguous role becomes precarious when the local students feel that their own internationalization project is badly served by the presence of English first-language speakers:

INT: um do you think it it mat- uhm

it matters what sort of English

that people speak here at the university

does it matter what sort of accent they have or

(2.5)

INF4: not at all

(o.3)

II think um 1

INT: [not at all no」

INF4: I'm (.) now it's more difficult for me to understand the real English (.)

INT: $\mathrm{mm}$

INF4: than um (o.7) whatever (o.2) mean I can understand (o.4)

German accent (o.7) French accent (.)

but when it comes to the (.) real English from mean the States or the um (.)

Unite- um or the um (o.3) Great Britain then it's like whuu (o.2)

then I have problems

(Mortensen, Fabricius 2014: 211)

What the students call "the real English" gives problems probably not so much because of the authentic accent (which educators would consider a good model for the learner and hence an asset), but because its speakers do not accommodate to the unaccustomed scenario of having to speak to other students who are not firstlanguage speakers themselves.

In several of his publications, the German-Chilean, Mexico-based sociolinguist Rainer Enrique Hamel has distinguished between research, publication and teaching as realms of language choice in academia (Hamel 2006, 2008). In all three areas, viz. teaching (formation), research (recherche scientifique), and publications (diffusion), we can today note a prominence of English, but for different reasons and as a result of quite different and not synchronous historical processes.

In Denmark, English-medium instruction was practically unknown outside English language and literature studies before the 1990s, as we have seen. The situation changed with the establishment of international programs which at least in part were motivated by the desire to attract students from abroad. The choice of English as the medium for those programs was motivated by the identification of "international" with "in English", supported by the notion that English by then had established itself as the unchallenged international language. This was certainly the case in Denmark

2 A similar observation from Spain: "I don't like the idea of having subjects taught in English at the University of the Basque Country, because we are here to improve our Spanish" (Doiz et al. 2013: 1415). 
(and the other Scandinavian countries, plus a few others): English had established itself as the default language for international academic contacts, and if Danish universities had to set up international programs, they had to be in English.

While English-medium instruction in international programs was new in the 9os, we know very little about the language situation at Danish research institutions in the $2 \mathrm{O}^{\text {th }}$ century, although we have reason to assume that English was not the default language for communication with visitors from abroad. In the 1950s, linguistics (with Louis Hjelmslev as the central figure) and physics (with Niels Bohr) had put Denmark on the map. We know about the languages of Hjelmslev's and Bohr's research publications and that they both spoke several languages besides Danish, but we know very little about the languages spoken by and with visiting scholars at their academic institutions. Some much later research (Madsen 2008) indicates, however, that Danish today still has a strong position as the daily language of research even in the natural science laboratories.

As far as the third area mentioned by Hamel is concerned, publication, up to World War II Danish research publications were spread over several languages, mostly French, German and English, apart from Danish, of course. Keeping a different pace in different academic disciplines, English has taken on a more and more important role, but this is a process that had started before, and independently of, the advent of English-medium instruction in the 1990s. (For one particular series in linguistics, the Travaux du Cercle linguistique de Copenhague, figures are given in Haberland 2008: 233.)

To take the example of Roskilde University, the number of Danish research publications (of all departments) for all years from 1995 to 2016 is 8,972, while the number for English is 15,254 and the total for all other languages is $1,143 .{ }^{3}$ Among these "other languages", German is relatively the largest with 348 publications, followed by French with 187, Swedish with 168, Italian with 84, Norwegian with 73 and Spanish with 66 publications. Except for Danish and English, figures for the individual years within the period fluctuate for all languages and there is no clear tendency. What is interesting, however, is the relative number of publications in English and Danish. The number of English publications per year increased between 1995 to 2016 from 368 to 797, while those in Danish increased much less, from 253 to 336 , in the same period.

The ratio between publications in English and Danish was 1.45:1 in 1995 and 2.37:1 in 2016 with a clear overall increase (although again in fits and starts). Moreover, there was a steady increase between 2003 (1.13:1) and 2009 (2.58:1), after which the curve flattened out and the ratio stabilized. This tendency of a widening gap between the publications in English and Danish (which did not prevail in the ten years before that either) did, interestingly, not continue after 2009.

The choice of a publication language for one's research is, of course, determined by several factors, and only one of them is the expected receptive language competence

Thanks to Ene Rammer Nielsen and Sidse Louise Schelde of Roskilde University Library for help with the data. Data until 2008 have been published in Mortensen, Haberland (2012: 189). 
of the researcher's intended audience. In Denmark, if one is aiming at an international audience, choosing English is the best bet because many people (but far from all) are relatively good at writing English, and one can assume that the knowledge of English is more widespread abroad than that of any other language. That not everybody outside Denmark reads English is probably the explanation for the occurrence of Japanese publications that are translations (at least in some of the cases from English). Another factor is the researchers' own first language: one could guess that publications in German, Swedish and Italian are written by teachers and researchers with those as first languages (and as such a consequence of the number of scholars from these countries employed at any time). A factor that has only come into the picture lately through research done in Sweden (Salö 2017) is that younger researchers publish more in English than the local language since the bibliometric system built up in recent years is heavily biased towards English-language publications, which is why publications in English further a scholar's career more than publications in other languages. This is obviously of more concern to scholars in their early career.

\section{The globalized corporation}

In the LInGCorp project, we investigated the language policies, language attitudes and language practices in Danish companies with an international outlook. Many of them had declared English as their corporate language (and one of them, a subsidiary to a German company, had gone from German to English about ten years previously). It is well known in language policy studies that there is almost always a difference between what people do, what people believe and the relevant rules:

... language practices, beliefs and management are not necessarily congruent. Each may reveal a different language policy. The way people speak, the way they think they should speak, and the way they think other people should speak may regularly differ (Spolsky 2004: 7)

But we have to further distinguish between two kinds of belief, viz. what people think they are supposed to do and what people think they actually do.

Declaring English as the corporate language is one thing; what happens on a daily basis something else. As one of the employees said:

Well, and it, it is, it is, we aren't, uh, not enough anyway. Uh (.) maybe, because we talk about being international, and the corporate language is English, but that is not the case on a daily basis.... Well, there will, there is, when you sit here, people don't really talk English to each other (Barfod Lund 2017: 102, interview in Danish)

In spite of this, there has been a rather visible and continuing concern in the media about the threat of yet another "domain loss" for Danish.

Talking about language regimes, Japan and Denmark may differ in many ways, but there has been the same media focus on the use of English in business, but with a less ambiguous, more positive attitude in Japan. In the public discourse in Japan, 
the use of English as a corporate language has been strongly associated with the challenges of business globalization, challenges that are obviously greater than in Denmark because English proficiency is clearly an elite phenomenon and not nearly as widespread in Japan as in Denmark. The icon of the introduction of English as a corporate language has become the CEO of the Rakuten e-commerce company, Hiroshi Mikitani (see also Neeley 2013).

An editorial in The Japan Times of May 23, 2015, stated that Mikitani

... based his company's global extension on employees following an English-only policy, which the company calls 'Englishnization'. All meetings, presentations, documents, training sessions and emails inside the company are conducted entirely in English. More than almost any other company in Japan, Rakuten has radically transformed its corporate policies - indeed its corporate culture - to embrace English as its working language.

We do not know what happens at Rakuten on a daily basis, but it seems that not all Japanese firms have an English-only policy based on the assumption that they can speak English with the rest of the world. In an interview we conducted in Tokyo in 2013, the language needs of a different company from Rakuten were described like this:

INF: ${ }^{4}$ but this company conduct what they call the store manager convention in which they invite all of the store managers from the world and that's biannually and eh [a translation company] is responsible for providing (0.5) translation services for Russian (o.6) Chinese (o.7) Korean (o.4) French (1.1) English (o.8) and Thai (o.6)

HAR: okay $>$ (3.0) and That's ?? 1

INF: $\quad$ land they] haven't started the German business here so [Germany is not included]

HAR: Lyeah mh:: Jis not included yeah

I thought I saw a shop in Berlin (0.5)

INF: they are building one it's not open yet

Here English is only mentioned as one of the many languages in which a Japanese firm does global business. There is no hint of the idea widely shared in Denmark that all the rest of the world speaks English. It is also made clear that English speakers in a globalized perspective really means 'speakers with multiple language competence':

INF: so they obviously demand for English speakers and I mean (o.5) bilingual speakers

HAR: yeah bilingual speakers so it's not English speakers from abroad

INF: but [more biling:1

HAR: Lbut Japanese] English speakers

INF: Japanese English speakers or non-Japanese (o.6) who can speak more than two languages (0.4)

4 $\mathrm{INF}=$ Informant, HAR = interviewer (Hartmut Haberland). 
It is interesting that in the view from Japan, Scandinavia appears as the region where English proficiency is everywhere, a source of admiration and even envy. When the interviewer asks about Scandinavia - when the firm opened a shop in Scandinavia, would they have to include the Scandinavian languages or just rely on English? - the answer is that in Scandinavia everybody, "even cab drivers", is fluent in English.

HAR: what about Scandinavia

they probably would expect that they can do: work in English

INF: well in Scandinavia even cab drivers speak a hundred percent fluent English

HAR: ah well not hundred per[cent but that's 1

INF:

Lat least my ... that was」 my experience

I was very surprised

Scandinavians, who are well aware of the fact that cab drivers, but not everybody else in their countries, may be fluent in English, might be "very surprised" themselves to hear that view.

Turning from language ideologies in Denmark to the actual experience on the company floor, there is a definite language gap within companies. In one pharmaceutical company, the difference was perceived as between those in the research department and the workers in the laboratories and in production. The need for and hence the actual use of English is attributed to "the academics" (university graduates), and to those who have offices with carpets on their floors and who travel.

DORTE: ${ }^{5}$ who in [your firm] uses English the most

SOFIE: that is the academics lyou know

LISA: Lyes 」

DORTE: in research

SOFIE: yeah yeah I yeah I only know about here what it's like here in research [right]

DORTE: $\quad$ Lyeah]

$$
\text { (2.0) }
$$

LISA: and then the higher-ups I guess

ANNA: yes

DORTE: what do you mean the higher-ups

JESPER: (chuckles)

LISBETH: the people with carpets on the floor

LISA:

XXX:

yes [(laughs)]

[(laughs)」

ANNA: well the vice presidents and those people right the people who travel, heads of division

(original in Danish, from Lønsmann 2015: 348)

SOFIE, LISA, ANNA, JESPER, LISBETH = employees, $\mathrm{XXX}=$ unidentified, DORTE $=$ Interviewer (Dorte Lønsmann). 
Even in Denmark one cannot take the capacity and willingness to use English in a globally oriented company for granted. Interview data from another company which has adopted English as its corporate language show that such a decision does not necessarily implement English as the language of daily interaction. In this company, the management decided to employ an English speaker in its HR team with the explicit aim of urging the other employees to speak English among themselves and thereby to create an "international mindset".

MOR: ${ }^{6} \quad$ so we have uh discussed a lot now that Sally has joined us she arrived in December this is actually the first time that we have a non-Danish-speaking employee in the team

DORTE: yes

MOR: um so we have we have spent some energy talking about what does that actually do to such a team

DORTE: $\mathrm{mmh}$

MOR: uh (.) we have agreed now that uh when Sally is here then we speak English and that is also if Anna and Leif are leaning over the table

DORTE: [mmh

MOR: Ljust 」 chit-chatting about something that happened over the weekend

(interview in Danish, Lønsmann 2017: 333)

It is remarkable that there is an explicit agenda of "recruiting internationally" in a double sense: on the one hand it shows that the Danish work force is able to cope with being confronted with the expectation of using English as their daily language of work, but on the other hand that it is also necessary to employ non-Danes to create a need to use English. Just declaring English the corporate language is not enough to achieve this goal.

MOR: and it was the same thing I said to Sally when I recruited her I said to Sally I know it will probably be hard for you

DORTE: yes

MOR: but you have to know that the reason that I am taking you in to be HR partner in the Danish part of the organization

$\rightarrow \quad$ is because you will also be a tool for me

$\rightarrow \quad$ to to set an agenda and 「drive an]

DORTE: $\lfloor\mathrm{mmh}\rfloor$

MOR: agenda

DORTE: yes

MOR: which means that now in the management groups Sally she is in well there they also speak English now [suddenlyl right

DORTE:

MOR: which they never did before Lyes 」

DORTE: so it does so there is also that agenda when lyoul MOR: Lyes 」

$6 \mathrm{MOR}=$ Morten (manager), DORTE $=$ interviewer (Dorte Lønsmann). 
DORTE: recruit linternaltionally

MOR: Lyes 」

(Lønsmann 2017: 337f.)

So using Sally as a tool to create an "international mindset" is only possible because Danes already have adopted English as their international language. They are just not ready to use the language they consider their international language at their home base unless they actually have to.

\section{Conclusion: English as a tool in internationalization}

We can see that both in Scandinavia and in Japan English is used as a tool to promote the goals of a globally oriented corporation. But this is done in different ways and cannot as such be counted as representing the same global trend, since the local conditions on which the use of English is based differ considerably. One could say that "globalization is crucially linked to the rise of English" ( $\mathrm{Hu} 2008$ : 35), but that does not mean that the crucial link is the same in all parts of the globe. Being a "world language" means very different things depending on where in the world you are. English is not simply "the world's lingua franca"; it is used in quite different ways to promote an international agenda in globally oriented corporations as well as institutions of higher learning.

In Scandinavia, and more specifically in Denmark, as a point of departure the population has developed widespread foreign language abilities (not just in English) since World War II, and we cannot talk about narrow elite multilingualism any more. Since access to English is widespread although still far from universal, the narrative of English as a world language interprets the situation as an opportunity to speak English with the rest of the world, if only the others spoke it like Scandinavians themselves.

In Japan, although many more have access to English than ever before, a different narrative has to prevail, since multilingualism still belongs to an elite (although the elite is widening). Hence world English is seen as a challenge rather than an opportunity. But this is combined with a stronger recognition of the need for other languages as well, not just English.

\section{References}

Airey J., Lauridsen K.M., Räsänen A., Salö L., Schwach V. 2017. The expansion of Englishmedium instruction in the Nordic countries: Can top-down university language policies encourage bottom-up disciplinary literacy goals? - Higher Education 73.4: 561-576.

Barfod Lund S. 2017. Sproglige praksisser i danske flersprogede virksomheders uformelle kontekster med fokus på tysk, svensk og norsk som regionale sprog. [Ph.D. thesis, Department of Communication and Arts, Roskilde University]. 
Bull T. 2004. Dagens og gårsdagens akademiske lingua franca. Eit historisk tilbakeblikk og eit globalt utsyn. - Simonsen D.F. (ed.). Språk I kommunikationssamfunnet. Engelsk elitenes nye latin? Oslo: 35-45.

Coleman J. 2013. Foreword. - Doiz A. et al. (eds.). English-medium instruction at universities. Bristol: xiii-xv.

Dalberg T. 2013. Engelskans utbredning i den svenska högskolan. En kartläggning av engelskspråkiga benämningar av program och kurser i svensk högre utbildning 1993-2009. [= Rapporter från Forskningsgruppen för utbildnings- och kultursociologi 52]. Uppsala.

Doiz A., Lasagabaster D., Sierra J. 2013. Globalization, internationalization, multilingualism and linguistic strains in higher education. - Studies in Higher Education 38.9: 1407-1421.

Fabricius A.H., Mortensen J., Haberland H. 2017. The lure of internationalization: Paradoxical discourses of transnational student mobility, linguistic diversity and cross-cultural exchange. - Higher Education 73.4: 577-595.

Haberland H. 2008. Domains and domain loss. - Preisler B. et al. (eds.). The consequences of mobility. Roskilde: 227-237.

Haberland H., Preisler B. 2015. The position of Danish, English and other languages at Danish universities in the context of Danish society. - Vila F.X., Bretxa V. (eds.). Language policy in higher education: The case of medium-sized languages. Bristol: 15-42.

Hamel R.E. 2006. Spanish in science and higher education: Perspectives for a plurilingual language policy in the Spanish-speaking world. - Current Issues in Language Planning 7.1: 95-125.

Hamel R.E. 2008. Les langues des sciences et de l'enseignement supérieur: état actuel et perspectives d'avenir. - Agence Universitaire de la Francophonie (AUF) \& Organisation Internationale de la Francophonie (OIF) (eds.). Séminaire international sur la méthodologie d'observation de la langue française dans le monde. Paris: 193-203.

Hazel S., Mortensen J. 2013. Kitchen talk - Exploring linguistic practices in liminal institutional interactions in a multilingual university setting. - Haberland H., Lønsmann D., Preisler B. (eds.). Language alternation, language choice and language encounter in international tertiary education. Dordrecht: 3-30.

$\mathrm{Hu}$ X. 2008. Teaching of culture in the context of English as an international language. Haberland H. et al. (eds.). Higher education in the global village. Roskilde: 35-40.

Lønsmann D. 2015. Language ideologies in a Danish company with English as a corporate language: 'It has to be English'. - Journal of Multilingual \& Multicultural Development 36.4: 339-356.

Lønsmann D. 2017. A catalyst for change: Language socialization and norm negotiation in a transient multilingual workplace. - Journal of Linguistic Anthropology 27.3: 326-343.

Madsen M. 2008. "Der vil altid voere brug for dansk". En undersøgelse af 11 naturvidenskabelige forskeres grunde til at voelge henholdsvis dansk og engelsk i deres arbejde. [= Københavnerstudier i tosprogethed 48]. Copenhagen.

Mortensen J., Fabricius A.H. 2014. Language ideologies in Danish higher education: Exploring student perspectives. - Hultgren A.K., Gregersen F., Thøgersen J. (eds.). English at Nordic universities: Ideologies and practices. Amsterdam: 193-223.

Mortensen J., Haberland H. 2012. English — the new Latin of academia? Danish universities as a case. - International Journal of the Sociology of Language 216: 175-197.

Neeley T. 2013. Language and globalization: 'Englishnization' at Rakuten. [= Harvard Business School Teaching Note 412-083].

Salö L. 2017. The sociolinguistics of academic publishing. Language and the practices of homo academicus. New York. 
Schiewe J. 2000. Von Latein zu Deutsch, von Deutsch zu Englisch. Gründe und Folgen des Wechsels von Wissenschaftssprachen. - Debus F. et al. (eds.). Deutsch als Wissenschaftssprache im 20. Jahrhundert. Mainz and Stuttgart: 81-104.

Spolsky B. 2004. Language policy. Cambridge. 